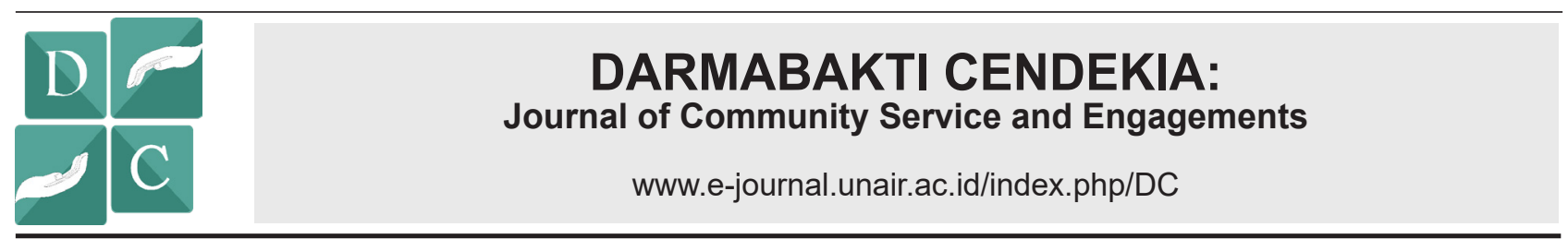

\section{DESINFECTION SOCIALIZATION OF MAKING DENTURES FOR AVOIDING CROSS INFECTION IN DENTAL ARTISANS AT KECAMATAN SAMBENG, LAMONGAN CITY}

\author{
SOSIALISASI DESINFEKSI PEMBUATAN GIGI TIRUAN UNTUK \\ MENGHINDARI INFEKSI SILANG PADA TUKANG GIGI DI \\ KECAMATAN SAMBENG, KABUPATEN LAMONGAN
}

\section{Scope:}

Health

\author{
Endang Kusdarjanti ${ }^{1}$ Okti Setyowati回, Sujati@ \\ IStudy Program of Dental Technique, Faculty of Vocational Studies, Universitas Airlangga, Surabaya-Indonesia
}

\begin{abstract}
A B S T R A C T
Background: Since time immemorial the existence of dental artisans has been neglected, even though many members of the community are involved as consumers of existing dental artisans. The dental artisans at Resik Village, Sambeng sub-district, Lamongan City do not yet know the dangers of cross infection when making dentures and how to do to prevent it. Objective: This activity aims to increase the awareness of dental artisans to avoid cross-infection between dental artisans and consumers. Method: This activity for the Resik Village community was carried out in the form of socialization to dental artisan partners, demonstrations on how to use disinfectant materials to dental artisans, as well as evaluation and monitoring of programs in the field. Results: This activity program was attended by 40 dental artisan participants where only 10 participants participated face-to-face due to the Covid 19 pandemic. Thirty other participants were given a video socialization of the activity. Disinfection socialization activities were carried out in 2 ways, namely disinfection by immersing teeth in a disinfectant solution and by dipping the teeth in a disinfectant solution. spray method. Conclusion: The participants gained additional knowledge about cross-infection, the consequences of these infections, and how to carry out disinfection when making dentures.
\end{abstract}

\section{A B S T R A K}

Latar belakang: Sejak dahulu kala keberadaan tukang gigi sering diabaikan, padahal banyak anggota masyarakat yang terlibat sebagai konsumen dari tukang gigi yang ada. Para tukang gigi di Desa Resik, Kecamatan Sambeng, Kabupaten Lamongan selama ini belum mengetahui bahaya infeksi silang saat pembuatan gigi tiruan dan bagaimana upaya yang harus dilakukan untuk pencegahannya. Tujuan: Kegiatan ini bertujuan untuk meningkatkan kesadaran para tukang gigi untuk menghindari terjadinya infeksi silang antara tukang gigi dengan konsumen. Metode: Kegiatan pengabdian kepada masyarakat Desa Resik ini dilakukan dalam bentuk sosialisasi pada mitra tukang gigi, demonstrasi cara penggunaan bahan desinfektan kepada tukang gigi, serta evaluasi dan monitoring program di lapangan. Hasil: Program kegiatan ini diikuti oleh 40 peserta tukang gigi dimana hanya 10 peserta yang ikut secara tatap muka langsung disebabkan pandemi Covid 19. Tiga puluh peserta lainnya diberikan video sosialisasi kegiatan. Kegiatan sosialisasi desinfeksi dilakukan dengan 2 cara yaitu desinfeksi dengan cara pencelupan gigi dalam larutan desinfektan dan dengan metode spray. Kesimpulan: Peserta mendapatkan tambahan pengetahuan tentang infeksi silang, akibat yang ditimbulkan dari infeksi tersebut, dan bagaimana cara melakukan desinfeksi saat pembuatan gigi tiruan.

\author{
ART ICLE INFO \\ Received 5 October 2020 \\ Revised 6 January 2020 \\ Accepted 31 May 2021 \\ Online 28 June 2021 \\ * Correspondence (Korespondensi): \\ Endang Kusdarjanti \\ E-mail: \\ endangkusdaryanti@gmail.com
}

Keywords:

Disinfection, Denture, Acrylic Resin, Dental Artisan

Kata kunci:

Desinfeksi, Gigi Tiruan, Resin Akrilik, Tukang Gigi 


\section{PENDAHULUAN}

Materi tentang ilmu kedokteran gigi modern yang terkait dengan pengetahuan dan teknologi telah sukses dan sangat maju menuju ranah kekinian, teknologi kedokteran gigi terus berkembang baik dalam bahan maupun alat yang telah ditemukan, memberikan konstribusi yang sangat berarti dalam bidang kedokteran gigi. Namun pada kenyataannya kebutuhan di lapangan dalam hal ini, masyarakat awam Indonesia, beberapa materi dasar terkait pengetahuan dan teknologi yang umum saja masih perlu banyak yang harus diluruskan. Salah satu cara yang bisa dilakukan yaitu melalui program pengabdian masyarakat berbasis kebutuhan masyarakat secara obyektif. Sebagai salah satu contoh sederhana yaitu mengenai keberadaan tukang gigi yang ada. Sejak dahulu kala keberadaan tukang gigi sering diabaikan, padahal banyak anggota masyarakat yang terlibat sebagai konsumen dari tukang gigi yang ada.

Kebutuhan setiap orang untuk memakai gigi tiruan cukup beragam, mulai dari kebutuhan untuk menggantikan gigi yang hilang, menggantikan gigi yang telah rusak dan ada juga yang dijadikan tanda status sosial di beberapa daerah. Pada umumnya masyarakat untuk memenuhi kebutuhan pembuatan gigi tiruan lebih memilih mengunjungi tukang gigi daripada pergi ke tempat praktek dokter gigi yang resmi dikarenakan harga yang jauh lebih murah.

Tukang gigi diartikan sebagai orang yang mempunyai kemampuan membuat dan memasang gigi tiruan tanpa mempunyai ijazah resmi dari Departemen Kesehatan dan dasar ilmu pengetahuan kedokteran gigi, tetapi melakukan pekerjaan menggunakan alat yang besar kesamaannya dengan dokter gigi. Tukang gigi diartikan sebagai pelaku usaha karena karena dalam melakukan pekerjaannya yaitu menawarkan jasa kepada konsumennya. Tukang gigi sebagai pelaku usaha menyediakan jasa yang diperuntukkan kepada masyarakat yang membutuhkan jasanya dan tukang gigi yang menyediakan jasa dapat memperoleh laba dan kepuasan dari konsumen atas produknya (jasa tukang gigi). Aturan pekerjaan tukang gigi telah diatur oleh pemerintah dalam hal ini Kementerian Kesehatan yang mengeluarkan peraturan terbaru mengenai tukang gigi yaitu Permenkes No 39 Tahun 2014 tentang Pembinaan, Pengawasan dan Perizinan, Pekerjaan Tukang Gigi. Dalam Permenkes tersebut telah diatur kewenangan dan standar pekerjaan tukang gigi.

Namun pengetahuan tentang kesehatan yang dimiliki oleh tukang gigi masih sangat rendah. Rendahnya pengetahuan tukang gigi dapat menyebabkan pada tindakan yang dapat membahayakan bagi kesehatan konsumen (Sugiarto \& Astiawati, 2017).

Pengendalian infeksi silang dalam bidang kedokteran gigi sangat penting. Hal ini dikarenakan kekhawatiran tentang penularan infeksi penyakit menular seperti, AIDS, hepatitis, TBC, pneumonia dan herpes antara pasien, dokter gigi dan teknisi gigi. Pembuatan gigi tiruan dapat beresiko tertular infeksi dari protesa gigi tiruan tersebut. Untuk itu para teknisi gigi dan dokter gigi sepakat bahwa protesa gigi perlu didesinfeksi sebelum dilakukan tindakan oleh teknisi gigi dan juga sebelum dikembalikan ke dokter gigi (Hussen, Rejab, \& Abbood, 2008; Zulkarnain \& B, Jefferson, 2014). Sama seperti hubungan profesional antara dokter gigi dan pasiennya demikian juga tukang gigi dan konsumennya yang rentan terkena infeksi silang apabila tidak mengetahui adanya infeksi silang dan bagaimana upaya untuk pencegahannya.

Di suatu daerah di Lamongan ada 2 desa yaitu desa Kedung Wangi dan desa Candisari. Di desa Candisari ada suatu dusun yaitu dusun Resik Kecamatan Sambeng Kabupaten Lamongan, sebagian besar penduduknya berprofesi sebagai tukang gigi. Tukang gigi sebagai penyedia jasa layanan pembuatan gigi tiruan rentan terkena infeksi silang dengan konsumennya. Tukang gigi seperti halnya teknisi gigi dalam melakukan pekerjaannya seharusnya menggunakan Alat Pelindung Diri (APD). APD yang seharusnya digunakan untuk mengurangi resiko infeksi silang tersebut yaitu dengan menggunakan masker sebagai pelindung hidung dan mulut, memakai kacamata serta sarung tangan. Sedangkan untuk pembuatan gigi tiruan dilakukan pencegahan dengan menggunakan bahan desinfektan mulai dari persiapan sampai gigi tiruan selesai dibuat dan siap untuk dipasang ke konsumen. Bahan desinfektan yang sering digunakan untuk desinfeksi gigi tiruan adalah klorheksidin dan larutan sodium hipoklorit (Anusavice, 2004; David \& Munadziroh, 2006; Nugrahini, 2020).

Kontrol infeksi yang buruk adalah masalah utama pada pembuatan gigi tiruan karena dapat menyebabkan infeksi silang antara pasien, dokter gigi dan teknisi gigi. Semua bahan dan peralatan yang digunakan dalam pembuatan gioi tiruan harus didesinfeksi dengan teliti (Sykes, 2019). Meningkatnya kesadaran akan penyakit menular dan pengetahuan tentang potensi penularan mikroorganisme infeksius selama prosedur pembuatan gigi tiruan telah menyebabkan meningkatnya kepedulian dan perhatian terhadap pencegahan infeksi di tempat praktek gigi.

Gigi yang terkontaminasi air liur pasien dan atau darah dapat menyebabkan kontaminasi silang. 
Pembuatan gigi tiruan dimulai dengan mencetak gigi pasien. Tahap mencetak juga memiliki potensi untuk penularan mikroba. Usaha yang dilakukan dengan mencuci cetakan dengan air saja dapat menghilangkan sedikitnya 40\% bakteri, virus, dan jamur. Cara tersebut sama sekali tidak memadai sebagai cara untuk mengurangi risiko infeksi potensial (Rentzia et al., 2011).

Tahap awal yang dilakukan pada konsumen oleh tukang gigi adalah mencetak gigi. Cetakan yang didapatkan harus segera dilakukan tindakan desinfeksi (Sastrodihardjo, 2016). Salah satu tahap yang juga perlu mendapat perhatian pada prosedur pembuatan gigi tiruan untuk mencegah infeksi silang yaitu tahap pemulasan gigi tiruan. Pada saat memulas gigi tiruan, yang digunakan yaitu mesin pulas, sikat, bubuk batu apung dan bahan untuk mengkilapkan gigi tiruan yang baru dan lama, tanpa ada yang didesinfeksi atau diganti alat dan bahan pulasnya. Padahal alat dan bahan pulas yang digunakan tersebut sangat berpotensi untuk terjadinya infeksi silang (Sykes, 2019).

Karena melihat pentingnya tindakan desinfeksi pada gigi tiruan yang harus dilakukan saat pembuatan gigi tiruan serta mengingat akibatakibat yang ditimbulkan apabila tidak dilakukan desinfeksi pada saat proses pembuatannya, maka sangat perlu dilakukan PengMas ini. PengMas ini bertujuan melakukan transfer ilmu pengetahuan dan teknologi kedokteran gigi dasar dan praktis berbasis kebutuhan masyarakat secara obyektif, mendapatkan pondasi yang cukup kuat dalam melaksanakan pengelolaan kesehatan para tukang gigi secara mandiri.

Oleh karena itu sangat perlu untuk dilakukan sosialisasi pada para tukang gigi di Ds Resik, Kecamatan Sambeng, Kabupaten Lamongan sehingga para tukang gigi yang diberikan sosialisasi kesehatan diharapkan dapat meningkatkan derajat kesehatan dengan cara menghindari infeksi silang sebagai bagian proses proteksi diri dan peningkatan kesehatan serta pencegahan penyakit menular.

Para tukang gigi di Ds Resik, Kecamatan Sambeng, Kabupaten Lamongan selama ini belum mengetahui:

1. Apakah yang dimaksud dengan infeksi silang saat pembuatan gigi tiruan?

2. Bagaimana akibatnya apabila saat pembuatan gigi tiruan tidak dilakukan tindakan desinfeksi?

3. Bagaimanakah cara melakukan desinfeksi pada saat pembuatan gigi tiruan?

Pencegahan penyakit dan promosi kesehatan merupakan upaya esensial di saat masih tingginya kejadian penyakit menular juga diiringi dengan semakin meningkatnya masalah penyakit tidak menular. Semakin tingginya beban masalah kesehatan masyarakat saat ini mengindikasikan bahwa promosi kesehatan dan pencegahan yang telah ada kurang dapat berkontribusi dalam meningkatkan derajat kesehatan masyarakat. Transfer IPTEK produk perguruan tinggi adalah salah satu aspek yang dipandang perlu untuk dituangkan kepada masyarakat mitra, dalam hal ini yang dipilih adalah warga Ds Resik, Kecamatan Sambeng, Kabupaten Lamongan dimana sebagian besar warganya berprofesi sebagai tukang gigi. Selama ini para tukang gigi tersebut belum pernah mendapatkan pengetahuan tentang adanya infeksi yang bisa disebabkan karena pembuatan gigi tiruan, belum pernah dilakukan promosi kesehatan dan pencegahan penyakit, sehingga perlu dilakukan inisiasi promosi kesehatan dan pencegahan penyakit yang berbasis masyarakat.

Dengan adanya sosialisasi tentang pentingnya untuk melakukan desinfeksi pada saat pembuatan gigi tiruan mulai dari mencetak gigi sampai siap untuk dipasang ke dalam mulut konsumen, para tukang gigi akan tahu dan menyadari tentang bahaya infeksi silang sehingga akan melakukan upaya untuk mencegahnya yaitu dengan melakukan desinfeksi.

\section{METODE}

Belajar mengaplikasikan kebiasaan baru membutuhkan waktu dan kesabaran, terutama bagi para tukang gigi yang sudah bekerja selama bertahun-tahun. Yang biasa mereka lakukan setelah mencetak gigi konsumen langsung akan dilakukan proses pembuatan gigi tiruan. Tidak pernah dilakukan desinfeksi terlebih dahulu. Saat diadakan sosialisasi maka mereka akan diberikan pengetahuan untuk melakukan tindakan desinfeksi terlebih dahulu sebelum dan setelah proses pembuatan gigi tiruan. Tentu hal tersebut bukan merupakan hal yang mudah untuk dilakukan. Beberapa hari sampai beberapa minggu merupakan periode penyesuaian agar diperoleh adaptasi yang disebabkan karena perubahan kebiasaan. Setelah terbiasa dianjurkan untuk selalu melakukannya demi kesehatan mereka sendiri. Untuk melakukan sosialisasi dalam pelaksanaan kegiatan pengabdian kepada masyarakat ini diperlukan dua tahap yaitu persiapan dan cara melakukan desinfeksi.

Pada tahap persiapan yang perlu dilakukan yaitu pembuatan surat ijin pelaksanaan ke Kepala Desa Resik, Kecamatan Sambeng, Kabupaten Lamongan. Kemudian survey lokasi dan sosialisasi kegiatan ke desa mitra. Disamping itu, menyediakan alat dan bahan yang diperlukan untuk pelaksanaan pengmas yaitu sendok cetak untuk mencetak gigi konsumen, alat dan bahan 
untuk memulas gigi tiruan, bahan desinfeksi, pembuatan leaflet dan X-banner, buku panduan cara melakukan desinfeksi gigi tiruan

Mensosialisasikan kepada para tukang gigi tentang dampak yang diakibatkan apabila gigi tiruan tidak didesinfeksi dimulai dengan langkah persiapan yang dilakukan pada saat mencetak gigi konsumen dengan melakukan desinfeksi pada cetakan yang tersebut. Juga diberi penjelasan kepada mereka bahwa desinfeksi adalah membunuh mikroorganisme penyebab penyakit dengan bahan kimia atau secara fisik, hal ini dapat mengurangi kemungkinan terjadinya infeksi dengan jalan membunuh mikroorganisme pathogen.

Setelah dilakukan pencetakan gigi pada konsumen selanjutnya cetakan tersebut dibilas dengan air kemudian dikeringkan dengan kertas tisu lalu dilakukan desinfeksi dengan menggunakan bahan desinfektan Natrium Hipoklorit ( $\mathrm{NaOCl})$ ), dengan cara disemprot pada seluruh permukaan cetakan atau dicelupkan kedalam cairan desinfektan.Untuk desinfeksi resin akrilik digunakan bahan khlorheksidin karena bahan tesebut mudah didapat dan tidak menyebabkan perubahan sifat fisik akrilik secara signifikan. Pemilihan cara dengan disemprot (spray). Spray sebagai salah satu cara membersihkan resin akrilik dari bakteri yang sudah teruji juga efektif.

Setelah pelaksanaan sosialisasi, dilakukan monitoring 1 bulan sebagai evaluasi pelaksanaan program dan keberlanjutan program di lapangan setelah kegiatan pengabdian kepada masyarakat selesai dilaksanakan. Kegiatan monitoring ini dilakukan karena membutuhkan waktu untuk merubah kebiasaan yang sudah bertahun-tahun dilakukan. Selanjutnya dilakukan pembuatan laporan kegiatan pengabdian pada masyarakat yang sudah selesai dilaksanakan.

\section{HASIL DAN PEMBAHASAN}

Kegiatan pengabdian kepada masyarakat ini diawali dengan rapat koordinasi bersama anggota tim pengabdian, mengurus perijinan, sosialisasi ke daerah mitra yaitu ke Kepala Desa Candisari (Bpk Hartono) dan Kepala Dusun Resik (Bpk Wiyono). Penyediaan bahan desinfeksi dan alat pendukung juga perlu dilakukan seperti buku panduan, X-banner dan leaflet (Gambar 1, 2 dar 3).

Pelaksanaan program dilakukan di Ds Resik, Kecamatan Sambeng, Kabupaten Lamongan, pada tanggal 3 September 2020. Tahap-tahap pelaksanaan yang dilakukan yaitu: Tahap pertama melakukan koordinasi dengan kepala desa dan kepala dusunnya. Yang bersedia untuk mengikuti program sebanyak 40 orang yang berprofesi sebagai tukang gigi.Desa tersebut mayoritas penduduknya bekerja sebagai tukang gigi. Bahkan kepala desa dan jajarannya juga sebagai tukang gigi. Pada saat sosialisasi direncanakan yang akan mengikuti acara sosialisasi 40 orang, tetapi karena adanya pandemi Covid-19, dan mengikuti anjuran protokol kesehatan, maka peserta yang hadir dibatasi 10 orang saja selain Bapak Kepala Desa, Bapak Carik dan Bapak Kepala Dusun. Pelaksanaan dilakukan di Pendopo Kelurahan, di ruangan terbuka. Semua peserta yang mengikuti sosialisasi maupun tim pengabdi semua menggunakan masker dan saat datang ke lokasi setiap orang diperiksa suhu tubuhnya dengan menggunakan alat Thermogun (Gambar 4).

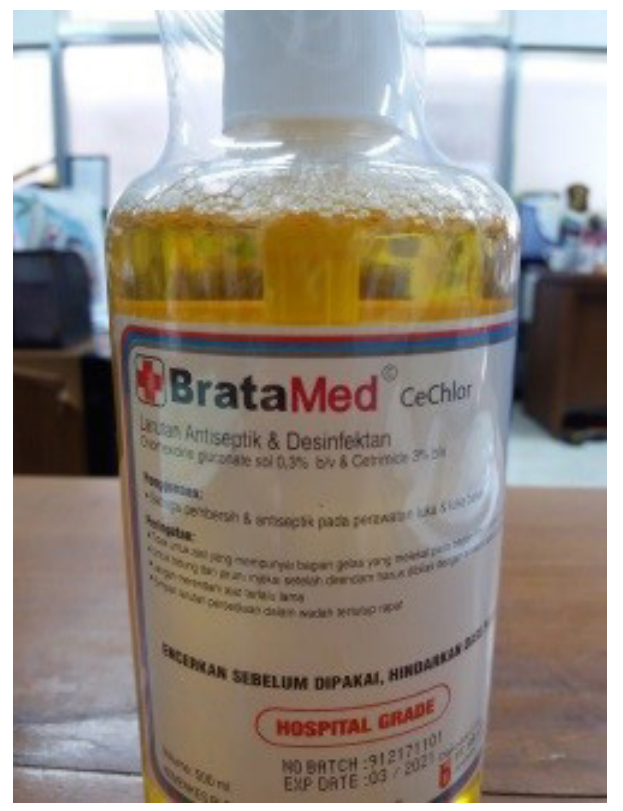

Gambar 1. Bahan desinfeksi yaitu Chlorhexidine (spray)

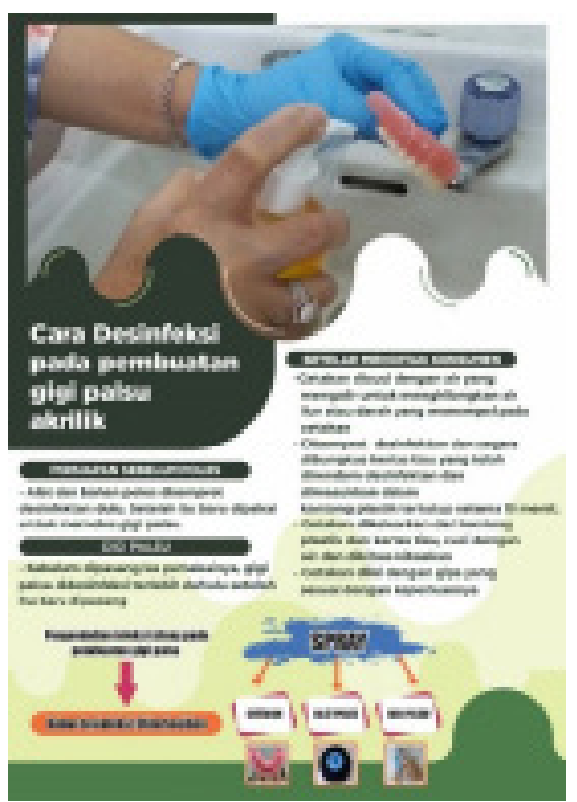

Gambar 2. Pembuatan leaflet 


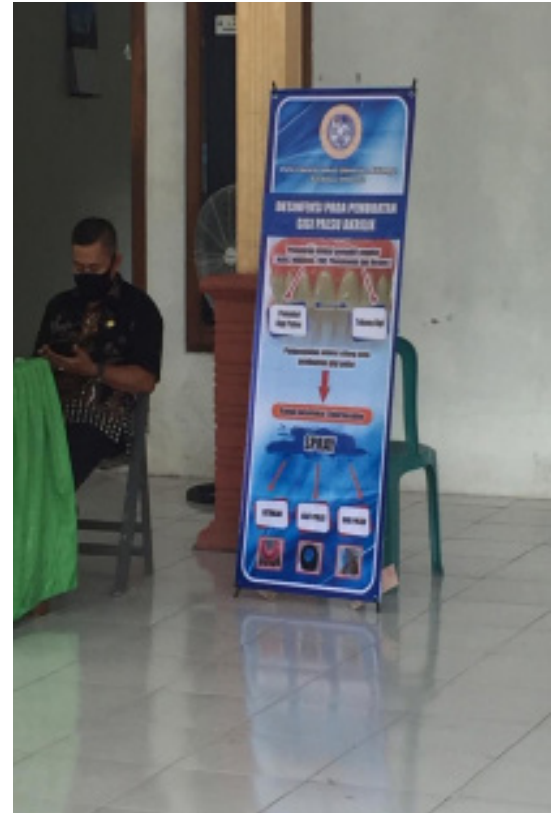

Gambar 3. X-banner yang sudah terpasang

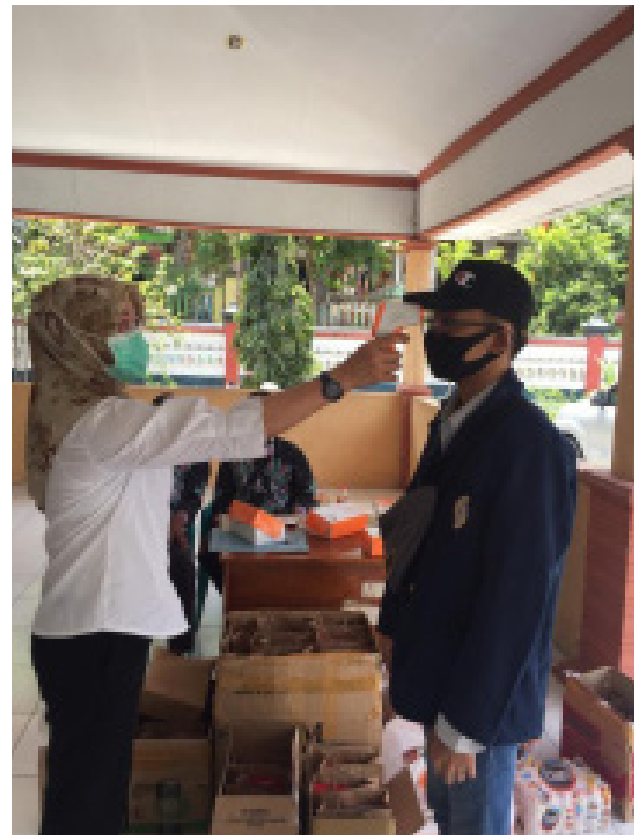

Gambar 4. Pemeriksaan suhu tubuh dengan Thermogun

Bagi 30 orang tukang gigi yang tidak bisa mengikuti secara langsung kegiatan tersebut sudah dibuatkan videonya dan dibagikan melalui WhatsApp, jadi mereka tetap mendapatkan materi tentang sosialisasi yang diberikan. Sosialisasi yang diberikan berupa edukasi tentang dampak yang diakibatkan apabila prosedur pembuatan gigi tiruan tidak dilakukan desinfeksi. Dilanjutkan demonstrasi cara menggunakan desinfektan.

Sosialisasi dilakukan dengan cara memberikan pengetahuan tentang langkah persiapan yang harus dilakukan setelah mencetak gigi konsumen yaitu dengan melakukan desinfeksi pada cetakan tersebut. Ada beberapa cara yang dapat dilakukan untuk tindakan desinfeksi terhadap kuman akibat infeksi silang yaitu ada dalam saliva dan menggantikan kalsium yang diperlukan sebagai perekat dengan cara pertama yaitu dicelupkan ke dalam larutan desinfektan. Cara kedua dengan disemprot (spray) dengan bahan desinfektan, dan cara ketiga yaitu dengan menggunakan microwave. Untuk sterilisasi gigi tiruan, ADA merekomendasikan perendaman gigi tiruan dalam desinfektan. Bahan desinfektan yang direkomendasi oleh ADA adalah alkalin glutaraldehid sedangkan desinfektan yang lazim digunakan rumah sakit di Indonesia adalah klorheksidin dan sodium hipoklorit.

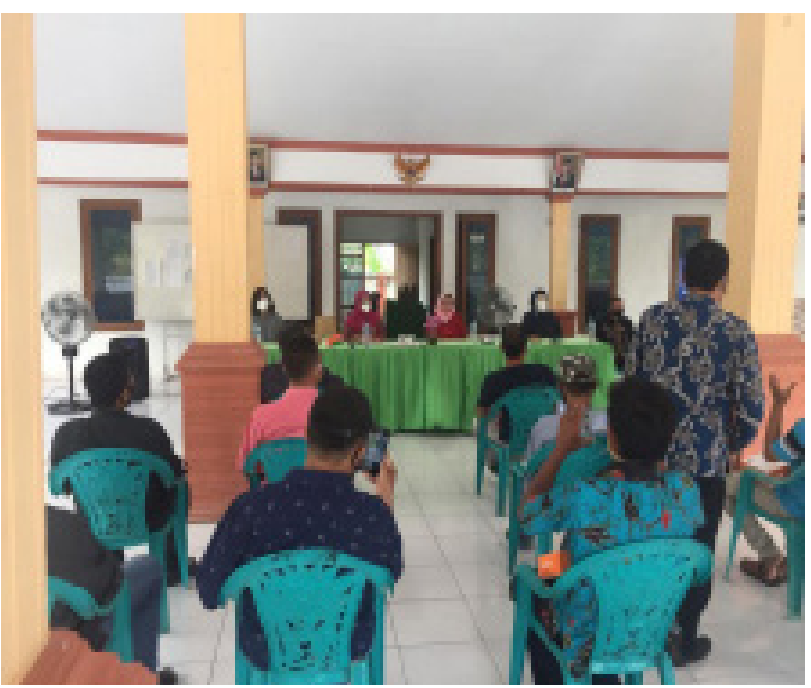

Gambar 5. Penyuluhan pada para tukang gigi di Ds Resik

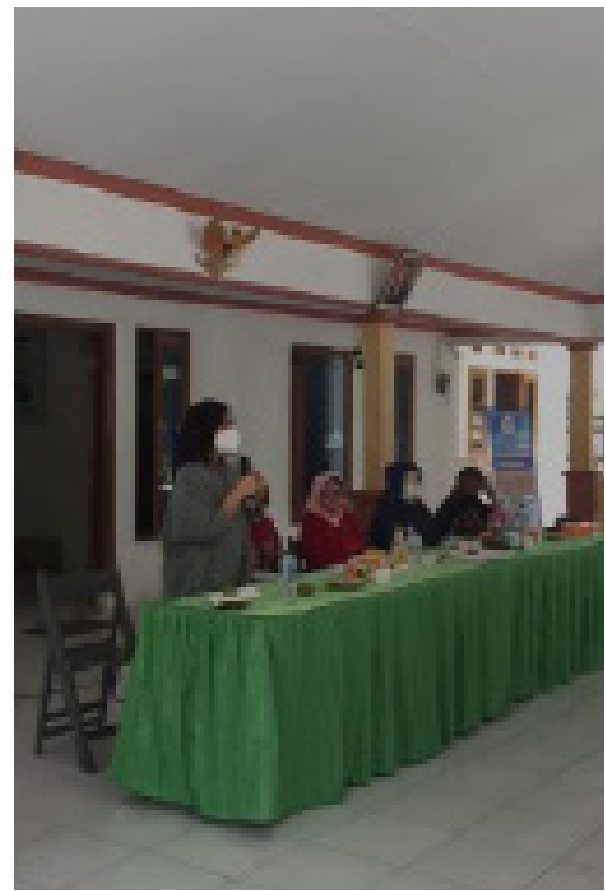

Gambar 6. Para tim pengabdi sedang memberikan sosialisasi 


\section{KESIMPULAN DAN SARAN}

Kegiatan sosialisasi diselenggarakan hanya selama 1 jam dan mendapat sambutan yang sangat baik dari para peserta. Peserta telah mengetahui tentang infeksi silang, akibat yang bisa ditimbulkan dan bagaimana cara melakukan desinfeksi saat pembuatan gigi tiruan. Demikian laporan pengabdian ini disusun untuk menjadi bahan acuan dalam meningkatkan kesadaran para tukang gigi yang bekerja di bidang jasa untuk melakukan pembuatan sampai pemasangan gigi tiruan pada konsumennya sehingga dapat menghindari terjadinya infeksi silang antar tukang gigi dan konsumennya. Pelaksanaan kegiatan masih banyak kekurangan-kekurangan sehingga masih jauh dari sempurna, maka melalui kesempatan ini, penulis mengharap masukan demi perbaikan yang akan datang.

Saran yang dapat kami rekomendasikan antara lain para tukang gigi sebaiknya juga mengikuti seminar tentang pembuatan gigi tiruan yang dapat menunjang kesehatan. Setelah mengikuti sosilisasi diharapkan para tukang gigi yang bersangkutan mau dan mampu mengembangkan dan meneruskan program ini dan menjalankannya rutin dalam melakukan pekerjaannya sehingga dapat mengurangi terjadinya infeksi silang.

\section{UCAPAN TERIMA KASIH}

Penulis mengucapkan terima kasih kepada Fakultas Vokasi Universitas Airlangga Tahun Anggaran 2020 yang telah membiayai Pengabdian kepada Masyarakat ini melalui Dana Rencana KegiatanAnggaranTahunan(RKAT). Sesuaidengan Surat Keputusan Rektor Universitas Airlangga tentang Pelaksanaan Program Pengabdian Kepada Masyarakat Universitas Airlangga Tahun 2020. Nomor 532/UN3/2020 Tanggal 1 Juli 2020. Penulis menyatakan tidak ada konflik kepentingan dengan pihak-pihak yang terkait dalam kegiatan pengabdian kepada masyarakat ini.

\section{DAFTAR PUSTAKA}

Anusavice, K.J. 2004. Phillips buku ajar ilmu bahan kedokteran gigi. Alih bahasa; Johan Arief Budiman, Susi Purwoko. Ed. 10. Jakarta: EGC. Pp. 29-61, 192-222.

David, \& Munadziroh, E. 2005. Perubahan warna lempeng resin akrilik yang direndam dalamlarutan desinfektan sodium hipoklorit dan klorhexidin. Dental Journal Vol. 38(1). Pp. 36-40.

Hussen, A.M., Rejab, L.T., \& Abbood, L.N. 2008. The effect of microwave disinfection on the dimensional change of acrylic resin. AlRafidain Dent J Vol. 8(1). Pp. 38-43.

Nugrahini, S. 2020. Perubahan Warna pada Plat Gigi Tiruan Resin Akrilik Polimerisasi Panas Setelah Perendaman dalam Larutan Desinfektan. SONDE (Sound of Dentistry) Vol. 5(1). Pp. 2335.

Rentzia, A., et al. 2011. Desinfection procedures: Their efficacy and effect on dimensional accuracy and surface quality of an irreversible hydrocolloid material. Journal of Dentistry Vol. 39(2). Pp. 133-140.

Sastrodihardjo, S. 2016. Desinfeksi Hasil Cetakan. Jurnal Material Kedokteran Gigi Vol. 5(2). Pp. 45-51.

Sugiarto, \& Astiawati, F. 2017. Tanggung jawab hukum pekerjaan tukang gigi terhadap konsumen penerima jasa tukang gigi di kota Semarang. Master Thesis. Semarang: Unika Soegijapranata. Pp. 1-116.

Sykes, L.M., et al. 2019. Microbial contamination of denture polishing equipment. South African Dental Journal Vol. 74(3). Pp. 116-122.

Zulkarnain, M., \& B, Jefferson, D. 2014. Pengaruh Perendaman Basis Gigi Tiruan Resin Akrilik Polimerisasi Panas dalam Larutan Sodium Hipoklorit dan Vinegar Cuka Putih Terhadap Kekasaran Permukaan dan Stabilitas Warna. Jurnal Material Kedokteran Gigi Vol. 3(1). Pp. 22-32. 